\title{
Kinetics of the Redox Reaction of Benzaldehyde and Dichromate Ions in Aqueous Acidic Medium
}

\author{
ATOLAIYE, BO; *EDWARD-EKPU, DU; ETUA, EC
}

Department of Chemistry, Nasarawa State University, Keffi, Nigeria

*Corresponding AuthorEmail: uwagbalae@gmail.com

\begin{abstract}
The kinetics of the redox reaction of benzaldehyde and dichromate ions in aqueous acidic media was determined. The data obtained was carried out at wavelength, $\lambda=420 \mathrm{~nm}$, acid $\left(\mathrm{H}_{2} \mathrm{SO}_{4}\right)$ was used to catalyze the reaction, $\left(\left[\mathrm{H}^{+}\right]=0.1 \mathrm{~mol} \mathrm{dm}^{-3}\right)$ and temperature $=35 \pm 0.5^{\circ} \mathrm{C}$. The stoichiometry of the reaction using the mole ratio method was found to be 5:1 ( $\mathrm{ArCHO}: \mathrm{Cr}_{2} \mathrm{O}_{7}{ }^{2-}$ ). The rate showed first order each with respect to the reductant and oxidant and second order overall. The overall rate law was predicted as; Rate $=\mathrm{k}_{2}[\mathrm{ArCHO}]\left[\mathrm{Cr}_{2} \mathrm{O}_{7}^{2-}\right]$, where $\mathrm{k}_{2}=$ second order rate constant for the reaction. The proposed rate equation for the reaction is: $\frac{-\mathrm{d}\left[\mathrm{Cr}_{2} \mathrm{O}_{7}{ }^{2-}\right]}{\mathrm{dt}}=\mathrm{k}_{2}[\mathrm{rCHO}]\left[\mathrm{Cr}_{2} \mathrm{O}_{7}{ }^{2-}\right]$. The reaction of $\mathrm{ArCHO}$ and $\mathrm{Cr}_{2} \mathrm{O}_{7}^{2-}$ was catalysed by $\mathrm{H}^{+}$through one pathway, the acid pathway. Michaelis- Menten plot showed a positive slope with no significant intercept and the absence of intermediate complex formation suggesting a spontaneous reaction.
\end{abstract}

\section{DOI: https://dx.doi.org/10.4314/jasem.v23i7.18}

Copyright: Copyright (C) 2019 Atolaiye et al. This is an open access article distributed under the Creative Commons Attribution License (CCL), which permits unrestricted use, distribution, and reproduction in any medium, provided the original work is properly cited.

Dates: Received: 23 May 2019; Revised: 20 June 2019; Accepted 19 July 2019

Keywords: Acid Catalysed, Redox Mechanism, Benzaldehyde, Chromate ions

The importance of kinetics studies of electron transfer reactions to chemistry can not be overemphasied. Redox processes which involve transfer of electrons are widely seen in one stage or the other in reactions involving inorganic and biological systems. Understanding, development and effective control of a wide area of science and technology would not be possible without an adequate knowledge of the redox processes taking place in these inorganic and biological system. Understanding in detail the mechanisms involved requires measurements of the reaction rates and the parameters on which the rates depend such as added ions, temperature etc. (Gorban and Yablonsky, 2015). Avariety of experimental tecchniques have been developed and used to investigate redox reactions (Goudar et al., 2004).The range of techniques used depends on how fast the reactions go. Many authors have extensively reviewed the techniques (Vandana et al., 2008), some of which include; conventional methods, fast reaction techniques etc. Benzaldehyde $\left(\mathrm{C}_{6} \mathrm{H}_{5} \mathrm{CHO}\right.$ or $\left.\mathrm{ArCHO}\right)$ is an organic compound consisting of a benzene ring with a formyl substituent. It is the simplest aromatic aldehyde and one of the most industrially useful. On oxidation, benzaldehyde is converted into the odourless benzoic acid, which is a common impurity in laboratory samples. Benzyl alcohol can be formed from benzaldehyde by means of hydrogenation (Jiang et al., 2010; Phonchaiya et al., 2009).

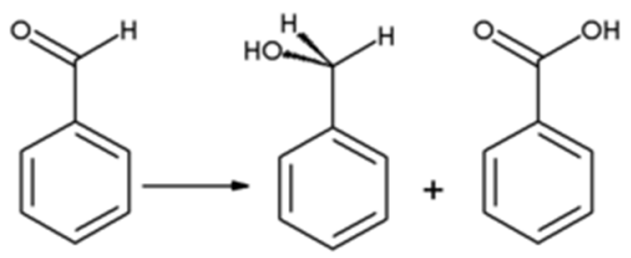

Oxidation of benzaldehyde (Jiang et al., 2010)

The chromate and dichromate ions are fairly strong oxidizing agents. Commonly three electrons are added to a chromium atom, reducing it to oxidation state +3 . In acid solution the aquated $\mathrm{Cr}^{3+}$ ion is produced (Haustein et al., 2014). 


$$
\begin{gathered}
\mathrm{Cr}_{2} \mathrm{O}_{7}^{2-}+14 \mathrm{H}_{3} \mathrm{O}^{+}+6 e^{-} \rightarrow 2 \mathrm{Cr}^{3+}+21 \mathrm{H}_{2} \mathrm{O} \\
\varepsilon_{0}=1.33 \mathrm{~V} .
\end{gathered}
$$

When used as oxidizing agents or titrants in a redox chemical reaction, chromate and dichromate convert into trivalent chromium, $\mathrm{Cr}^{3+}$, salts of which typically have a distinctively different blue-green colour (Obafemi, 2000; Anger et al., 2005). Potassium dichromate is an oxidizing agent in organic chemistry, and is milder than potassium permanganate. It is used to oxidize alcohols. It converts primary alcohols into aldehydes and, under more forcing conditions, into carboxylic acids. In contrast, potassium permanganate tends to give carboxylic acids as the sole products. Secondary alcohols are converted into ketones. For example, menthone may be prepared by oxidation of menthol with acidified dichromate (Anger et al., 2005; Master, 2003).

The aim of this research work is to determine the mechanistic pathway for the reaction of benzaldehyde and dichromate ions through the study and investigation of some kinetic parameters which affect the rate of redox reaction of benzaldehyde with dichromate ions such as follows the stoichiometry of the reaction, determination of the reaction order with respect to the concentration of the oxidant and the pseudo-first and second order rate constants.

\section{MATERIALS AND METHODS}

The materials used for this study are as follows: Benzaldehyde, potassium heptaoxochromate (vi), tetraoxosulphate (vi), distilled water and sodium carbonate. All chemicals and reagents used were of analytical grade and were used without further purification. Distilled water was used for preparing all solutions. Tetraoxosulphate (vi) acid was used as a medium for reaction while potassium heptaoxodichromate (vi) was used as oxidant. Other equipment and apparatus used for this research are: An analytical weighing balance, volumetric flasks filter funnel, beakers, conical flasks and UV/Visible spectrophotometer.

Preparation of Benzaldehyde solution: Benzaldehyde $(3.18 \mathrm{~g})$ was weighed and dissolved in a $100 \mathrm{~cm}^{3}$ volumetric flask which was made up to the mark with distilled water to prepare $0.3 \mathrm{~mol} \mathrm{dm}^{-3}$ benzaldehyde solution.
Preparation of Dichromate $\left(\mathrm{Cr}_{2} \mathrm{O}_{7}{ }^{2-}\right)$ : Potassium heptaoxodichromate (vi) (2.94g) was weighed and dissolved in a $100 \mathrm{~cm}^{3}$ volumetric flask and made up to the mark using distilled water to prepare $0.1 \mathrm{~mol}$ $\mathrm{dm}^{-3}$ potassium heptaoxodichromate (vi) solution.

Preparation of Tetraoxosulphate (vi) Acid $\left(\mathrm{H}_{2} \mathrm{SO}_{4}\right)$ : Tetraoxosulphate (vi) acid was prepared by diluting an appropriate volume $\left(5.6 \mathrm{~cm}^{3}\right)$ of concentrated $\mathrm{H}_{2} \mathrm{SO}_{4}$ $(96 \%)$ in a $100 \mathrm{~cm}^{3}$ standard volumetric flask and made up to the mark using distilled water to prepare a $0.1 \mathrm{~mol} \mathrm{dm}^{-3}$ stock solution of the tetraoxosulphate (vi) acid. The acid was then standardized volumetrically (titrimetrically) using sodium carbonate as primary standard. Lower concentrations can be obtained by serial dilution.

The Stoichiometric Studies and Kinetics measurement was carried out using the methods adopted from similar studies carried out by Mohammed et al. (2009) and Myek et al. (2014).

Stoichiometric Studies: The mole ratio method was used to determine the stoichiometry of the reaction of benzaldehyde and potassium dichromate ions by spectrophotometric titration. Keeping the concentration of the benzaldehyde constant and varying the concentration of the dichromate (oxidant) between the mole ratios of 1:0.1-1:0.7, that is keeping ArCHO at a constant concentration of $9 \times 10^{-3} \mathrm{~mol} \mathrm{dm}^{-}$ ${ }^{3}$ and varying the concentration of $\mathrm{Cr}^{2} \mathrm{O}_{7}{ }^{2-}$ ranging from $0.5 \times 10^{-3}$ to $6.0 \times 10^{-3} \mathrm{~mol} \mathrm{dm}^{-3}$. The absorbance of the reaction was measured at intervals of 5 minutes for 20 minutes. The concentration of the hydrogen ion, $\left[\mathrm{H}^{+}\right]$, was maintained at $0.1 \mathrm{moldm}^{-3}$. The reaction was allowed to go to completion at $35 \pm 0.5^{\circ} \mathrm{C}$ and $\lambda_{\max }=$ $420 \mathrm{~nm}$. The absorbance of the solution was taken using Cecil instrument UV visible spectrophotometer. The stoichiometry was determined from the plot of absorbance versus [reductant]/[oxidant] at the completion of the reaction (Mohammed et al., 2009; Myek et al., 2014).

Kinetics measurement: The rate of reaction was determined under pseudo-first order condition by varying the concentration of the oxidant $\left(\mathrm{K}_{2} \mathrm{Cr}_{2} \mathrm{O}_{7}\right)$ ranging from $0.5 \times 10^{-3}$ to $6.0 \times 10^{-3} \mathrm{~mol} \mathrm{dm}^{-3}$ and at a constant concentration of the benzaldehyde, which was in large excess (20-fold) of concentration of benzaldehyde. The increase in absorbance of the 
benzaldehyde was monitored using the Cecil instrument UV visible spectrophotometer at the wavelength of $420 \mathrm{~nm}$. The absorbance of the reaction was measured at intervals of 5 minutes until constant values were obtained. This whole procedure was done using varying volumes $(5,10,20,40,50,60 \mathrm{ml})$ of the dichromate. The pseudo-first order rate constant, $\mathrm{k}_{1}$, were obtained by plotting a graph of $\log \left(A_{t}-A_{0}\right)$ versus time $\left(A_{t}\right.$ is the absorbance at time, ' $t$ ' and $A_{0}$ is the absorbance at the end of the reaction), the values were taken from the slope of the plot. The second order rate constant, $\mathrm{k}_{2}$, was determined from $\mathrm{k}_{1}$ as $\frac{k_{1}}{\left[\mathrm{Cr}_{2} \mathrm{O}_{7}^{2-}\right]}$ (Mohammed et al., 2009; Myek et al., 2014).

\section{RESULTS AND DISCUSSION}

Stoichiometry: In the reaction of benzaldehyde (ArCHO) and dichromate ion $\left(\mathrm{Cr}_{2} \mathrm{O}_{7}^{2-}\right)$, the stoichiometry was determined from the titration curves. The plots show a sharp break at a $\mathrm{Cr}_{2} \mathrm{O}_{7}{ }^{2-}$ concentration of $2 \times 10^{-3} \mathrm{~mol} \mathrm{dm}^{-3}$ as shown in Figures 1 and 2 . This shows that $2 \times 10^{-3} \mathrm{~mol} \mathrm{dm}^{-3}$ of $\mathrm{Cr}^{2} \mathrm{O}_{7}{ }^{2-}$ is the amount required to fully react with a $9 \times 10^{-3} \mathrm{~mol}$ $\mathrm{dm}^{-3}$ of $\mathrm{ArCHO}$, indicating a $\mathrm{ArCHO} / \mathrm{Cr}_{2} \mathrm{O}_{7}{ }^{2-}$ mole ratio of 9:2. This means that 5 mole of benzaldehyde reacted with 1 mole of dichromate. This is consistent with the equation (1).

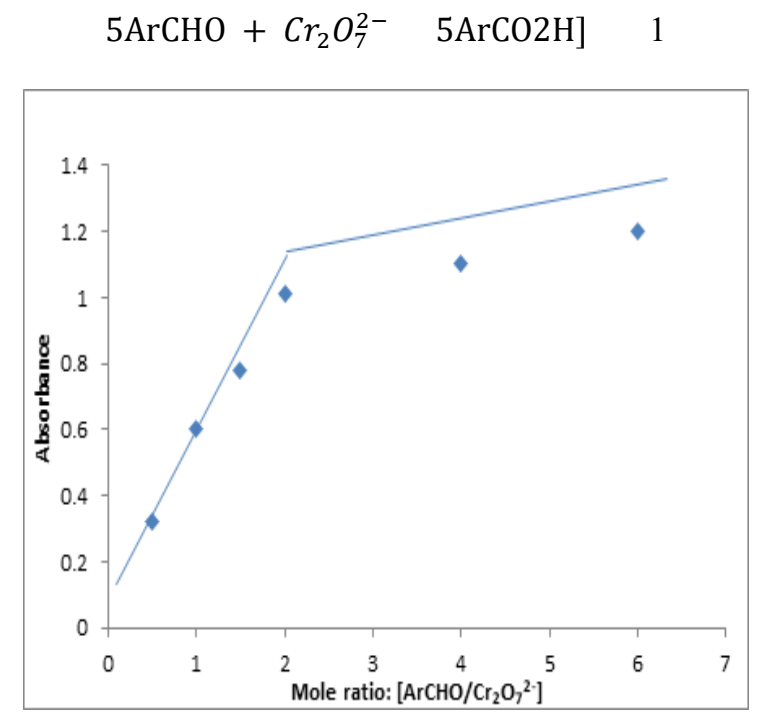

Fig 1: Plot of absorbance versus mole ratio for the reaction of benzaldehyde and dichromate. $[\mathrm{ArCHO}]=9 \times 10^{-3} \mathrm{~mol} \mathrm{dm}^{-3}$; $\left[\mathrm{Cr}_{2} \mathrm{O}_{7}^{2-}\right]=(0.5-6.0) \times 10^{-3} \mathrm{~mol} \mathrm{dm}^{-3} ;\left[\mathrm{H}^{+}\right]=0.1 \mathrm{~mol} \mathrm{dm}^{-3} ; \lambda_{\max }=420$ $\mathrm{nm}$; Temperature $=35 \pm 0.5^{\circ} \mathrm{C}$ at 5 minutes.

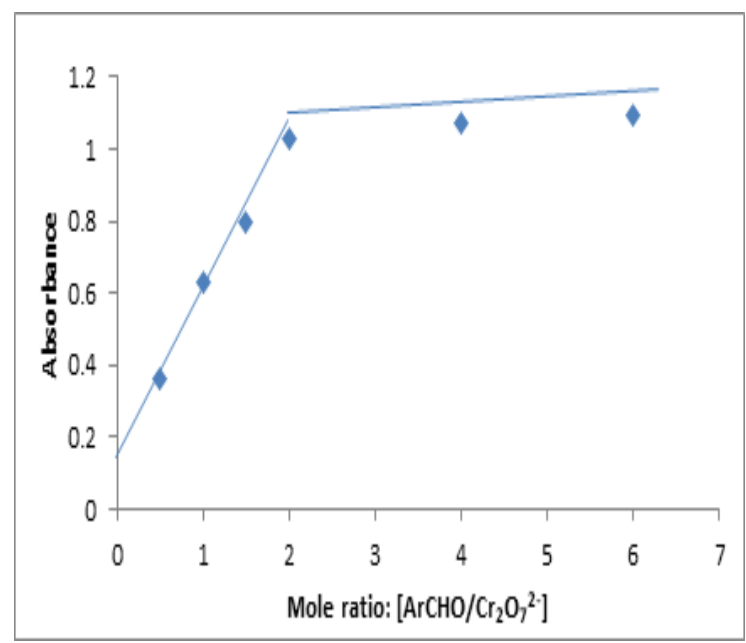

Fig 2: Plot of absorbance versus mole ratio for the reaction of benzaldehyde and dichromate. $[\mathrm{ArCHO}]=9 \times 10^{-3} \mathrm{~mol} \mathrm{dm}^{-3}$; $\left[\mathrm{Cr}_{2} \mathrm{O}_{7^{2-}}\right]=(0.5-6.0) \times 10^{-3} \mathrm{~mol} \mathrm{dm}^{-3} ;\left[\mathrm{H}^{+}\right]=0.1 \mathrm{~mol} \mathrm{dm}^{-3} ; \lambda_{\max }=420$ $\mathrm{nm}$; Temperature $=35 \pm 0.5^{\circ} \mathrm{C}$ at 20 minutes.

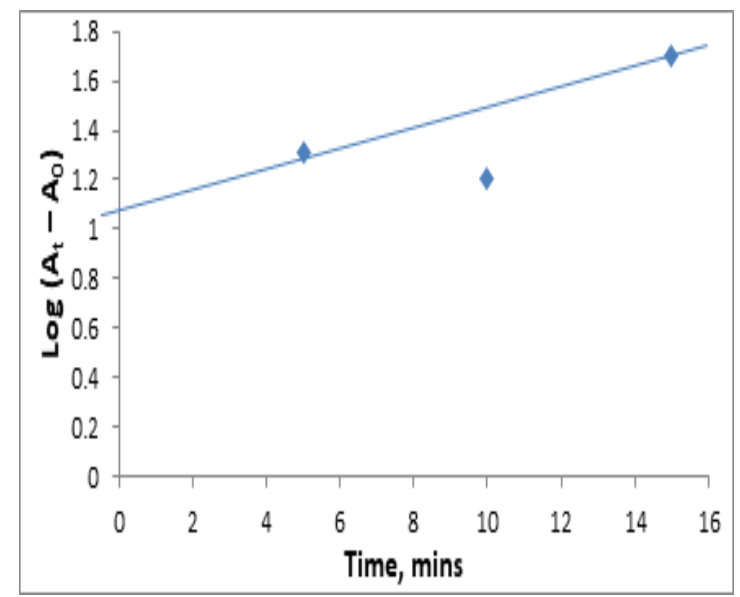

Fig 3: Pseudo first-order plot for the reaction of benzaldehyde and dichromate. $[\mathrm{ArCHO}]=0.3 \mathrm{~mol} \mathrm{dm}{ }^{-3} ;\left[\mathrm{Cr}_{2} \mathrm{O}_{7}{ }^{2-}\right]=(0.5-6.0) \times 10^{-3}$ $\left.\mathrm{mol} \mathrm{dm} \mathrm{dm}^{-3} ; \mathrm{H}^{+}\right]=0.1 \mathrm{~mol} \mathrm{dm}{ }^{-3} ; \lambda_{\max }=420 \mathrm{~nm} ;$ Temperature $=35 \pm$ $0.5^{\circ} \mathrm{C}$ at $5 \mathrm{ml}$ of the dichromate.

Order of reaction: The reaction rates were obtained under pseudo - first order conditions with $\mathrm{ArCHO}$ concentration in more than 20 -fold excess over $\mathrm{Cr}_{2} \mathrm{O}_{7}{ }^{2-}$ concentration. Usually, the rate of reaction is a function of the concentration of the reactants. The hydrogen ion concentration was maintained at $0.1 \mathrm{~mol}$ $\mathrm{dm}^{-3}$ and temperature $35 \pm 0.5^{\circ} \mathrm{C}$. Pseudo-first order rate constant $\mathrm{k}_{1}$ was determined at different concentrations of the dichromate ion, typical plots of $\log \left(A_{t}-A_{o}\right)$ against time are shown in Figs. 3 and 4. The linearity of the graphs suggests that the reaction is 
first order with respect to dichromate. A plot of $\log \mathrm{k}_{1}$ versus $\log \left[\mathrm{Cr}_{2} \mathrm{O}_{7}{ }^{2-}\right]$ as shown in Figure 5 was linear with a slope of 0.9 , suggesting that the reaction is first order with respect to each reactant. This means the reaction is second-order overall and is consistent with equation (2).

$$
\frac{-d\left[\mathrm{Cr}_{2} \mathrm{O}_{7}{ }^{2-}\right]}{d t}=\mathrm{k}_{2}[\mathrm{ArCHO}]\left[\mathrm{Cr}_{2} \mathrm{O}_{7}{ }^{2-}\right] \quad 2
$$

Michaelis-Menten Plot : A plot of $1 / k$ versus $1 /\left[\mathrm{Cr}_{2} \mathrm{OT}^{2-}\right]$ (Fig 6) was linear with a positive slope suggesting the absence of intermediate complex.

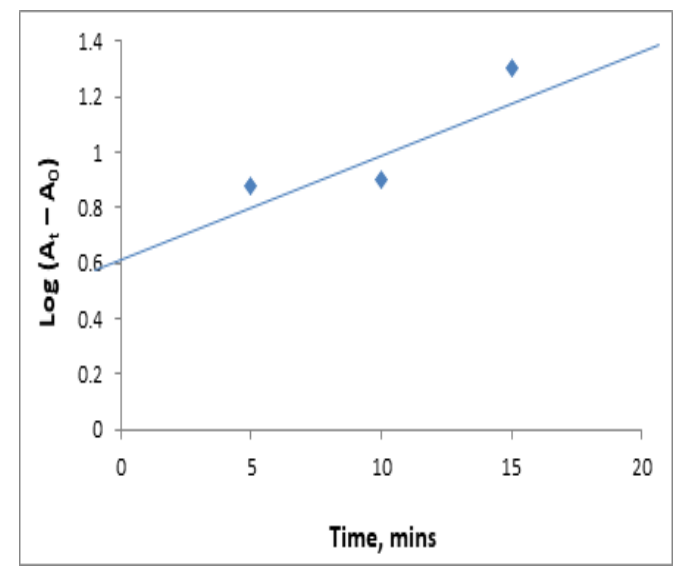

Fig 4: Pseudo first-order plot for the reaction of benzaldehyde and dichromate. $[\mathrm{ArCHO}]=0.3 \mathrm{~mol} \mathrm{dm}^{-3} ;\left[\mathrm{Cr}_{2} \mathrm{O}_{7}^{2-}\right]=(0.5-6.0) \times 10^{-3}$ mol dm ${ }^{-3} ;\left[\mathrm{H}^{+}\right]=0.1 \mathrm{~mol} \mathrm{dm}^{-3} ; \lambda_{\max }=420 \mathrm{~nm} ;$ Temperature $=35 \pm$ $0.5^{\circ} \mathrm{C}$ at $60 \mathrm{ml}$ of the dichromate.

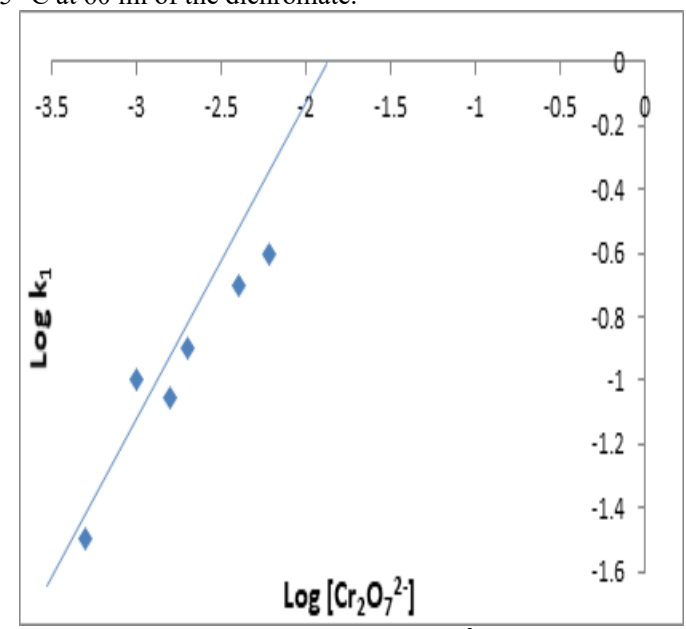

Fig 5: Plot of $\log \mathrm{k}_{1}$ versus $\log \left[\mathrm{Cr}_{2} \mathrm{O}_{7}^{2-}\right]$ for the reaction of benzaldehyde and dichromate ion. $[\mathrm{ArCHO}]=0.3 \mathrm{~mol} \mathrm{dm}^{-3}$; $\left[\mathrm{Cr}_{2} \mathrm{O}_{7}^{2-}\right]=(0.5-6.0) \times 10^{-3} \mathrm{~mol} \mathrm{dm}^{-3} ;\left[\mathrm{H}^{+}\right]=0.1 \mathrm{~mol} \mathrm{dm}^{-3} ; \lambda_{\max }=420$ $\mathrm{nm}$; Temperature $=35 \pm 0.5^{\circ} \mathrm{C}$.

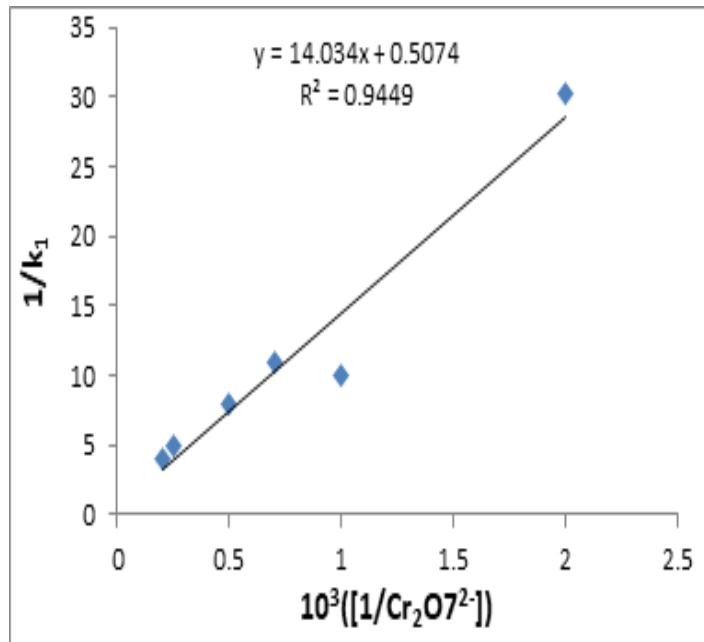

Fig 6: Plot $1 / \mathrm{k}_{1}$ versus $1 /\left[\mathrm{Cr}_{2} \mathrm{O}_{7}{ }^{2-}\right]$ for the reaction of benzaldehyde and dichromate ion. $[\mathrm{ArCHO}]=0.3 \mathrm{~mol} \mathrm{dm}^{-3} ;\left[\mathrm{Cr}_{2} \mathrm{O}_{7}{ }^{2-}\right]=(0.5-6.0)$ x $10^{-3} \mathrm{~mol} \mathrm{dm}^{-3} ;\left[\mathrm{H}^{+}\right]=0.1 \mathrm{~mol} \mathrm{dm}^{-3} ; \lambda_{\max }=420 \mathrm{~nm} ;$ Temperature $=35 \pm 0.5^{\circ} \mathrm{C}$

Conclusion: The kinetics of the redox reaction of benzaldehyde and dichromate ions in aqueous acidic medium showed that the reaction is first order with respect to both reactants and therefore second order overall. The reaction of $\mathrm{ArCHO}$ and $\mathrm{Cr}_{2} \mathrm{O}_{7}{ }^{2-}$ was catalysed by $\mathrm{H}^{+}$through one pathway, the acid pathway. Michaelis-Menten Analysis showed the absence of intermediate complex formation suggesting a spontaneous reaction.

\section{REFERENCES}

Anger, G; Halstenberg, J; Hochgeschwender, K; Scherhag, C; Korallus, U; Knopf, H; Schmid, P; Ohlinger, M (2005). Chromium compounds. Ullmann's Encycl. Ind. Chem. Weinheim: Wiley$\mathrm{VCH}$.

Gorban, AN; Yablonsky, GS (2015). Three Waves of Chemical Dynamics. Math. Mod. Nat. Phen. 10(5): 1-5.

Goudar, CT; Harris, SK; McInerney, MJ; Suflita, JM (2004). Progress curve analysis for enzyme and microbial kinetic reactions using explicit solutions based on the Lambert $\mathrm{W}$ function. $J$. Microb. Meth. 59 (3): 317-326.

Haustein, CH; Lerner, KL; Lerner, BW (2014). Oxidation-reduction reaction. The Gale 
Encyclopaedia of Science. $5^{\text {th }}$ edition. Farmington Hills, MI: Gale Group.

Jiang, X-D; Matsukawa, S; Kakuda, K-I; Fukuzaki, Y; Zhao, W-L; Li, L-S; Shen, et al. (2010). Efficient synthesis of tetradecafluoro-4-phenylheptan-4-ol by a Cannizzaro-type reaction and application of the alcohol as a bulky Martin ligand variant for a new anti-apicophilic phosphorane. Dalton Trans. 39: 9823-9829.

Master, FJ (2003). Diseases of Skin. B Jain Pub Pvt Ltd. New Delhi: P. 223.

Michaelis, L; Menten, ML; Johnson, KA; Goody, RS (2011). The original Michaelis constant: translation of the 1913 Michaelis-Menten paper. Biochem.. J. 50 (39): 8264-8269.

Mohammed, Y; Iyun, JF; Idris, SO (2009). Kinetic approach to the mechanism of the redox reaction of malachite green and permanganate ion in aqueous acidic medium. Afr. J. Pure. Appl. Chem. 3(12):269-274.
Myek, B; Idris, SO; Iyun, JF (2014). Kinetics and Mechanism of the Oxidation of Naphthol Green B by Peroxydisulphate Ion in Aqueous Acidic Medium. Int. J. Inorg. Chem., 2014 Volume, Article ID 768575, 4 pages

Obafemi, CA (2000). Concept in chemical reduction. Oxidation-Reduction Reaction $1^{\text {st }}$ ed. Obafemi Awolowo University Press Limited P. 160

Phonchaiya, S; Panijpan, B; Rajviroongit, S; Wright, T; Blanchfield, JT. (2009). Facile Solvent-Free Cannizzaro Reaction. J. Chem. Educ. 86: 85.

Sharma, V; Sharma, KV; Bhagwat, VW (2008). Kinetics and mechanistic study of cetyltrimethylammonium bromide catalyzed oxidation of tetraethylene glycol by Nchlorosaccharin in acidic medium. E-J Chem. 5 (3):598-606. 